Research Report

\title{
ANTIBACTERICAL POTENCY OF CALCIUM HYDROXIDE AND PROPOLIS MIXTURE ON MIXED BACTERIA OF CARIOUS DENTIN
}

\author{
ABSTRACT \\ Ruslan Effendy ${ }^{1}$, Vita Ariesta ${ }^{2}$, Widya Saraswati ${ }^{1}$ \\ ${ }^{1}$ Staff Department of Conservative Dentistry, Dental Medicine Faculty, Airlangga Univeristy, Surabaya - \\ Indonesia \\ ${ }^{2}$ Undergraduate Student of Dental Medicine Faculty, Airlangga University, Surabaya - Indonesia
}

Background: Calcium hydroxide has been known as the gold standard of pulp capping process, but still has some weaknesses such as a pH that is too high to be potentially toxic, resistant to certain bacteria, causing necrosis of the pulp, and causing a tunnel defect. This weakness causes researchers to look for alternative ingredients that have antibacterical properties that can be combined with calcium hydroxide. Propolis has antibacterial properties such as flavonoids, tannins, saponins, and terpenoids which can work as the best carrier that allows dissociation of ions from calcium hydroxide so the combination of both that has antibacterial power is expected to have an effective antibacterial potency against the number of bacterial colonization with mixed dentine carious. Aims: This study aims to determine the antibacterial potency produced by a combination of calcium hydroxide and propolis against mixed bacteria of carious dentine. Methods: The research was carried out using 4 treatment groups with each of 7 samples. Group I is a combination of calcium hydroxide and propolis with a ratio of 1: 1, group 2 with a ratio of $1: 1.5$, group 3 with a ratio of 1: 2, and a positive control group. Each sample was put into a suspense of mixed bacteria of carious dentine, grown for 24 hours. Suspense is vortexed for 1 minute so the solution becomes homogeneous. Put $0.1 \mathrm{ml}$ of suspended mixed bacteria of dentine carious from BHIB media, grown for 24 hours on MHA media and counted the number of colonies. Results: The highest number of colonies in the positive control group, then group 1, group 2, and the least number of colonies in group 3 with the most extract of propolis. Conclusion: The combination of calcium hydroxide and propolis with a ratio of 1: 2 has the best antibacterial power in inhibiting colonization of mixed bacteria of carious dentine.

Keywords: calcium hydroxide, propolis, mixed bacteria of dentine carious, antibacterical potency

Correspondence: Prof. Dr. Ruslan Effendy, drg., MS., Sp.KG(K), Dental Medicine Faculty, Universitas Airlangga, Surabaya - Indonesia, +62816516243, ruslan-e@fkg,unair.ac.id

\section{BACK GROUND}

According to Data of Riset Kesehatan Dasar (RISKERDAS) 2013, the population of Indonesia who had problems with dental and oral health was $25.9 \%$. While $72.3 \%$ had a history of caries, and around $53.2 \%$ for active children ${ }^{1}$. Dental caries is a chronic disease that is most commonly used for people, and is multifactorial. Dental caries is caused by various factors, such as microbes and products produced, genetic, behavioral, and environmental interrelated in the onset and development of dental caries ${ }^{2}$.

The process of caries usually starts from superficial namely enamel caries, but if it did not treat well, it will become caries 
which involves deeper tissue namely pulp dentin complex. This deep caries can cause bacterial invasion into the pulp space which can cause necrosis ${ }^{3}$.

Members of the streptococcal group; Streptococcus mutans, and Streptococcus sabrinus are considered as primary etiologies that induce caries. Another study identifying microorganisms found in dentinal caries is Lactobacillus spp ${ }^{2}$. Untreated and continuing caries dentine can become more severe and can cause pulp necrosis and cause the pulp to become unnecessary. Therefore, the treatment in the field of conservation is as much as possible maintaining pulp vitality by using effective treatment pulp capping ${ }^{4}$.

Pulp capping treatments are treatments using biocompatible materials on the pulp that are open both due to trauma and iatrogenic ${ }^{5}$. This treatment aims to form reparative dentin and eliminate the cariogenic bacteria involved so that the vitality of the pulp can be maintained. Products derived from calcium hydroxide are the agents most often used to treat deep carious lesions ${ }^{6}$. Pulp capping consists of 2 types, namely direct and indirect pulp capping. When the dental pulp is exposed, the technique used is direct pulp capping. The indirect pulp capping technique is used in conditions where there is still a thin layer of dentin ${ }^{7}$.

Calcium hydroxide is generally used as pulp capping material, intracanal medical material, root canal filling material, and pulpotomy treatment ${ }^{8}$. Calcium hydroxide has long been the gold standard in pulp capping treatments because it has an antibacterial effect and has the ability to stimulate the formation of reparative dentin ${ }^{7}$. Calcium hydroxide works by increasing the occurrence of mineralization from healthy dentine, the occurrence of soft dentin remineralization and dentine sterilization that has infection. This calcium hydroxide has an alkaline $\mathrm{pH}$ so that it can affect or change the environment so that bacteria cannot develop and provide neutral conditions so that stimulation of hard tissue formation occurs ${ }^{8}$.

Calcium hydroxide has disadvantages such as being resistant to certain bacteria: Enterococcus faecalis, Candida species, and Actinomyces radicidentis ${ }^{9}$. Calcium hydroxide is applied directly to the pulp tissue, necrosis can occur in adjacent pulp tissue, and cause inflammation of the surrounding tissue ${ }^{8}$. Calcium hydroxide in the treatment of pulpotomy of primary teeth can cause pulp necrosis and apical periodontitis $^{10}$. Based on these shortcomings, new material from nature with minimal side effects, and high antibacterial activity attracted the attention of researchers to be combined with calcium hydroxide to see its effectiveness, one of which is propolis ${ }^{9}$.

Propolis is a natural resin substance collected by bees from plant buds or extrudates. Honey bees use propolis as a cover hole or gap from their nest, also protect their nests from insect attacks. Propolis has also been used for a long time as a traditional medicine because some active ingredients, such as flavonoids, terpenoids, saponins, caffeic acid penethyl esters (CAPE), etc. it can be as antibacterial, anti-inflammatory, and immunomodulatory ${ }^{11}$. Propolis has been shown to rarely cause allergic reactions and is not toxic ${ }^{12}$.

Flavonoids contained in propolis can inhibit microorganisms by denaturing proteins and nucleic acids that can cause coagulation and freezing of proteins. Flavonoids also cause disruption of bacterial metabolism which results in insufficient energy requirements so that cells from bacteria are permanently damaged and cause bacterial death ${ }^{13}$. Because calcium hydroxide and propolis both have antibacterial effects, in this study we want to know the antibacterial power of a combination of calcium hydroxide and propolis.

It is wise to conduct a study of minimal inhibitory concentrations and the concentration of killing a minimum of 
propolis extract against mixed caries dentine bacteria. The minimum concentration of kill concentration obtained by propolis extract on mixed dentin caries bacteria is $8 \%{ }^{14}$. Ozorio proved that there is reparative dentin formation in a combination of calcium hydroxide - propolis in a ratio of $1: 1^{15}$. In addition, in Leo's research, the combination of calcium hydroxidepropolis against the number of Lactobacillus acidophilus bacteria and the ratio of 1: 2 had the best antibacterial power16. Therefore, in this study we want to know the antibacterial combination of calcium hydroxide and propolis against mixed dentin caries bacteria with a ratio of $1: 1,1: 1.5$ and $1: 2$.

\section{MATERIALS AND METHODS}

All tools used in this study were first sterilized in Autoclave (Oxoid, UK) for 30 minutes at a temperature of $121^{\circ} \mathrm{C}$.

1000 grams of Apis melifera honeycomb in the form of solids are cut into small pieces with approximately half to $1 \mathrm{~cm}$ in diameter and then inserted into the extractor and added with $1000 \mathrm{ml}$ of $96 \%$ ethanol in a closed container and mixed until all propolis is submerged in ethanol solution. Then shake with a shaker to make it homogeneous for $3 \times 24$ hours. After that maceration is stopped and filtered. From the results of filtration obtained a thin, clear liquid from propolis. After that, clear liquid from propolis was evaporated with a vacuum evaporator with a temperature of $50 \mathrm{Oc}-60 \mathrm{Oc}$. Then the propolis extract in the form of a brownish liquid with a concentration of $100 \%$ pure propolis $^{15}$.

Making 8\% concentration of propolis solution formulation using dilution method from $100 \%$ propolis extract solution using sterile distilled water.

The combination of calcium hydroxide with propolis extract was made by mixing calcium hydroxide powder (analysis of Merck, Germany) and Apis melifera bee propolis extract with a ratio of $1: 1(0.125$ gram calcium hydroxide powder with $0.125 \mathrm{ml}$ propolis extract), 1: 1.5 (powder calcium hydroxide 0.125 gram with propolis extract $0.1875 \mathrm{ml}$ ), 1: 2 (calcium hydroxide powder 0.125 grams with 0.25 $\mathrm{ml}$ propolis extract), and as a control group of material calcium hydroxide mixed with distilled distilled water ${ }^{16}$.

Preparing stock of deep carious mixed bacteria on MHA media. Then make a deep carious bacterial suspension suspense on BHIB media by inserting one colony into the test tube containing BHIB. Incubation for 24 hours at $37^{\circ} \mathrm{C}$. The concentration of bacteria is adjusted to the standard 0.5 Mc Farland (1.5 x 108 CFU / $\mathrm{ml})^{17}$.

The combination of calcium hydroxide-propolis and sterile calcium hydroxide were added to the mixed bacterial culture of dentine caries on BHIB media for 24 hours. Then take a combination of calcium hydroxidepropolis and sterile calcium hydroxideaquadest, and put it in the BHIB media. Vortex is performed for 1 minute. Take 0.1 $\mathrm{ml}$ of the BHIB into the MHA solid media and level it using a spreader. Add in jar and gas genering kit, then incubate at $37^{\circ} \mathrm{C}$ for 24 hours. Manually calculate dentine carious mixed bacterial colonies grown on Muller Hinton media and expressed with colony forming units (CFU). The calculation is repeated three times by three different observers ${ }^{17}$.

\section{RESULT}

This study aims to determine the antibacterial strength of the combination of calcium hydroxide-propolis against colonization of dentine carious mixed bacteria using an experimental unit consisting of a positive control group (a combination of sterile calcium hydroxide), treatment group I (a combination of calcium hydroxide-propolis with a ratio of 1: 1), treatment group II (combination of calcium hydroxide-propolis with a ratio of 1: 1.5), and treatment group III (combination of calcium hydroxide- 
propolis with a ratio of $1: 2$ ), with each experimental unit group as many as 7 samples. The average research results are shown in table 1

Table 1. Average and standard deviation of the number of dentine carious mixed bacterial colonies in colony forming units.

\begin{tabular}{|l|l|l|l|}
\hline Groups & $\mathbf{N}$ & $\bar{X}$ & S.D. \\
\hline Control & 7 & 74.43 & 1.718 \\
\hline I & 7 & 41.71 & 1.496 \\
\hline II & 7 & 28.57 & 2.637 \\
\hline III & 7 & 11.57 & 1.718 \\
\hline
\end{tabular}

Table description:

- Positive control $=$ calcium hydroxide

- Group I = combination of calcium hydroxidepropolis 1: 1

- Group II = combination of calcium hydroxidepropolis $1: 1.5$

- Group III = combination of calcium

hydroxide-propolis 1: 2

\section{ANALIZE OF THE RESEARCH RESULT}

From the data above, to determine whether homogeneous research data is tested for homogeneity using Levene's Test. From the homogeneity test obtained $p=0.198(p>0.05)$, meaning that the research data obtained is homogeneous.

After the homogeneity test, to find out whether the research data is normally distributed, a normality test is conducted. The normality test in each group was carried out using the Shapiro-Wilk test. The normality test for the combination group of calcium hydroxide and sterile distilled water obtained $\mathrm{p}=0.958(\mathrm{p}>$ 0.05 ), the combination group of calcium hydroxide and propolis 1 : 1 obtained $\mathrm{p}=$ 0.591 ( $p>0.05$ ), a combination group of calcium hydroxide and propolis 1: 1.5 obtained $\mathrm{p}=0.744$ ( $\mathrm{p}>0.05)$, and the combination group of calcium hydroxide and propolis 1: 2 obtained $\mathrm{p}=0.958(\mathrm{p}>$ $0.05)$. In the normality test obtained $p>$ 0.05 in all treatment groups, this means that the research data obtained is normally distributed.
After the normality and homogeneity test, the data analysis was continued to find out whether there were significant differences between treatment groups using different tests with One Way ANOVA. On the results of different tests, the value of $p=0.000(p<0.05)$ indicates that there are significant differences between treatment groups.

Next to find out the differences between treatment groups, the Tukey Honestly Difference (HSD) Post-Hoc test was carried out. The test results in each treatment group can be seen in table 2 .

Table 2 Different tests between groups treated with Honestly Significant Difference.

\begin{tabular}{|c|c|c|c|c|}
\hline $\begin{array}{c}\text { Research } \\
\text { Group }\end{array}$ & Control & $\begin{array}{c}\text { Combination } \\
\text { of CaOH- } \\
\text { Propolis 1:1 }\end{array}$ & $\begin{array}{c}\text { Combination } \\
\text { of CaOH- } \\
\text { Propolis } \\
\mathbf{1 : 1 , 5}\end{array}$ & $\begin{array}{c}\text { Combination } \\
\text { of CaOH- } \\
\text { Propolis 1:2 }\end{array}$ \\
\hline Control & - & $\mathrm{p}=0.000^{*}$ & $\mathrm{p}=0.000^{*}$ & $\mathrm{p}=0.000^{*}$ \\
\hline $\begin{array}{c}\text { Combination } \\
\text { of CaOH- } \\
\text { Propolis 1:1 }\end{array}$ & $\begin{array}{c}\mathrm{p}= \\
0.000^{*}\end{array}$ & - & $\mathrm{p}=0.000^{*}$ & $\mathrm{p}=0.000^{*}$ \\
\hline $\begin{array}{c}\text { Combination } \\
\text { of CaOH- } \\
\text { Propolis } \\
\text { 1:1,5 }\end{array}$ & $\begin{array}{c}\mathrm{p}= \\
0.000^{*}\end{array}$ & $\mathrm{p}=0.000^{*}$ & - & $\mathrm{p}=0.000^{*}$ \\
\hline $\begin{array}{c}\text { Combination } \\
\text { of CaOH- } \\
\text { Propolis 1:2 }\end{array}$ & $\begin{array}{c}\mathrm{p}= \\
0.000^{*}\end{array}$ & $\mathrm{p}=0.000^{*}$ & $\mathrm{p}=0.000^{*}$ & \\
\hline
\end{tabular}

Description: $*$ there is a significant difference with $\mathrm{p}<0.05$

From the data above, it was found that there were significant differences between the combination group of calcium hydroxide and aquadest sterile with a combination of calcium hydroxide and propolis $1: 1$ with $\mathrm{p}=0.000$ ( $\mathrm{p}$ $<0.05$ ) which means the combination group of calcium hydroxide and propolis 1: 1 had antibacterial power which is better than the combination of sterile calcium hydroxide and aquadest.

There was a significant difference between the combination group of calcium hydroxide and distilled aquadest with a combination of calcium hydroxide and propolis $1: 1.5$ with $\mathrm{p}=0.000(\mathrm{p}<0.05)$ which means that the combination group of calcium hydroxide and propolis 1: 1.5 had better antibacterial power compared to the combination of sterile calcium hydroxide and aquadest. 
There was a significant difference between the combination group of calcium hydroxide and distilled aquadest with a combination of calcium hydroxide and propolis 1: $1: 2$ with $\mathrm{p}=0.000(\mathrm{p}<0.05)$, which means that the combination group of calcium hydroxide and propolis 1: 2 had better antibacterial strength with a combination of sterile calcium hydroxide and aquadest.

The combination of calcium hydroxide and propolis with a ratio of 1: 1 showed a significant difference with the combination group of calcium hydroxide and propolis 1: 1.5 with $\mathrm{p}=0.000$ ( $\mathrm{p}$ $<0.05$ ), which means the combination group of calcium hydroxide and propolis 1: 1.5 has better antibacterial power compared to the combination of calcium hydroxide and propolis 1: 1 .

The combination of calcium hydroxide and propolis with a ratio of 1: 1 shows a significant difference with groups $1: 2$ with $p=0.000(p<0.05)$ which means that the combination group of calcium hydroxide and propolis 1: 2 has better antibacterial strength compared to the combination of calcium hydroxide and propolis 1: 1 .

The combination of calcium hydroxide and propolis with a ratio of 1 : 1.5 showed a significant difference with groups $1: 2$ with $p=0.000(p<0.05)$ which means that the combination group of calcium hydroxide and propolis 1: 2 has better antibacterial strength compared to combination of calcium hydroxide and propolis 1: 1.5 .

All treatment groups had a $\mathrm{p}$ value of $<0.05$, which meant that there were significant differences between treatment groups. This shows that the combination of calcium hydroxide propolis with a ratio of 1: 1, 1: 1.5, and 1: 2 has antibacterial properties against mixed bacterial dentine caries.

\section{DISCUSSION}

This study was conducted to determine the antibacterial power of a combination of calcium hydroxide and propolis to the amount of mixed bacterial colonization of dentine caries. Propolis has been used for a long time because it has active components such as flavonoids, terpenoids, tannins, and saponin. Propolis is a good carrier for calcium hydroxide which allows dissociation and shows a greater inhibitory power ${ }^{18}$. Calcium hydroxide combined with propolis will form calcium salt compounds with active compounds antibacterial compounds derived from propolis. Asmoro's research also proved that the research group coupled with propolis extract showed greater inhibition in inhibiting bacterial growth compared to the experimental group without propolis ${ }^{19}$. According to Mori et al., The combination of calcium hydroxide and propolis is also biocompatible with the best ratio of 1: 220 . In this study 4 research groups were used, namely the positive control group (combination of calcium hydroxide and sterile aquadest), treatment group I (combination of calcium hydroxide and propolis with a ratio of $1: 1$ ), treatment group II (combination of calcium hydroxide and propolis in a ratio of 1: 1), 5), and treatment group III (combination of calcium hydroxide and propolis in a ratio of 1:2).

The results showed a combination of calcium hydroside and propolis with a ratio of 1: 2 showed the least number of bacterial colonies with an average of 11.57 colonies compared to other treatment groups, namely a combination of calcium hydroxide - propolis with a ratio of 1.5, 28.57 colonies. The combination of calcium hydroxide - propolis with a ratio of $1: 1$ is 41.71 colonies. Finally, a combination of sterile calcium hydroxide aquadest is 74.43 colonies. This is in accordance with the study of Mori et al., That with a ratio of 1: 2 calcium hydroxide dissociates best into calcium and hydroxyl ions and shows a greater inhibitory power $^{20}$. The results of the study are also in accordance with Leo's research that the 
ratio of 1: 2 is the most effective comparison in inhibiting bacterial colonization because the combination of calcium hydroxide-propolis calcium salt compounds are formed with active compounds derived from the most propolis extract $^{16}$.

These results occur because the greater the comparison, the more the amount of propolis extract used is also. The more propolis extracts, the more the percentage of antibacterial compounds in the combination, indicated by the phytochemical test that the ratio of 1:2 shows the highest percentage of antibacterial compounds compared to other treatment groups so that the ability to kill bacteria is getting better. Active ingredients such as flavonoids, tannins, hydroxyl ions, saponins, and terpenoids function as antibacterials contained in propolis extract.

This is in accordance with the phytochemical test at the BPKI Laboratory on propolis extract showing the active content of flavonoids $4.81 \%$, tannin $0.31 \%$, hydroxyl ion $1.88 \%$, saponin $3.56 \%$, and terpenoid $4.05 \%$. The combination of calcium hydroxidepropolis with a ratio of 1: 1 shows the active content of $0.019 \%$ flavonoids, tannin $0.012 \%, 0.084 \%$ hydroxyl ion, $0.011 \%$ saponin, and $0.021 \%$ terpenoid. The combination of calcium hydroxidepropolis with a ratio of $1: 1.5$ shows the active content of flavonoids $0.211 \%$, tannin $0.021 \%$, hydroxyl ions $0.102 \%$, saponins $0.146 \%$, and terpenoid $0.136 \%$. The combination of calcium hydroxidepropolis with a ratio of 1: 2 shows the active content of flavonoids $0.220 \%$, tannin $0.034 \%$, hydroxyl ions $0.114 \%$, saponins $0.181 \%$, and terpenoid $0.165 \%$.

The control group that used a combination of calcium hydroxide and sterile aquadest had the highest number of bacterial colonization compared with other treatment groups, namely a combination of calcium hydroxide and propolis with a ratio of $1: 1,1: 1.5$, and 1: 2 with an average of 74.43 colonies. This shows that the combination of calcium hydroxide and sterile aquadest does not have an effective antibacterial effect against colonization of mixed bacterial dentinal caries. This is also in accordance with Asmoro's research which states that calcium hydroxide combined with propolis extract has a higher antibacterial power compared to calcium hydroxide without propolis19. This also happens because there is no addition of propolis extract which means this group has the least antibacterial compounds compared to the other three experimental groups, so that the number of bacteria colonies that are inhibited was reduced.

In this study, it was found that the combination group of calcium hydroxide and propolis with a ratio of 1: 2 had greater antibacterial power than the control group, the group treated with a combination of calcium hydroxide and propolis with a ratio of $1: 1$ and a combination of calcium hydroxide and propolis with a ratio of $1: 1.5$ while the combination group of calcium hydroxide and propolis with a ratio of $1: 1.5$ still has greater antibacterial power compared to the group treated with a combination of calcium hydroxide and propolis with a ratio of 1: 1 . This shows that calcium hydroxide combined with propolis has a higher antibacterial power compared to calcium hydroxide without propolis. Therefore, a combination of calcium hydroxide and propolis can be developed further to be used as an alternative to pulp capping.

\section{CONCLUSSION}

The combination of calcium hydroxide and propolis with a ratio of $1: 2$ has the best antibacterial power against colonization of mixed bacterial dentine caries.

\section{REFERENCES}

1. Riset Kesehatan dasar (Riskesdas), 2013, Badan Penelitian dan 
Pengembangan Kesehatan Kementrian RI tahun 2013. pp.111,118

2. Struzycka, I. 2014. The oral microbiome in dental caries.', Polish journal of microbiology / Polskie Towarzystwo Mikrobiologow $=$ The Polish Society of Microbiologists, 63(2):127-135.

3. Zara Viale. 2014. Dental Caries and Other Diseases of The Hard Tissues of The Teeth and Dental Pulp. Milan: SICS sirl, pp. 11

4. Neelakantan, P., Rao, C. V. S. and Indramohan, J. 2012. 'Bacteriology of deep carious lesions underneath amalgam restorations with different pulp-capping materials - an in vivo analysis', Journal of Applied Oral Science, 20(2):139-145.

5. Jalan, A., Warhadpande, M. and Dakshindas, D. 2017. 'A comparison of human dental pulp response to calcium hydroxide and Biodentine as direct pulp-capping agents', Journal of Conservative Dentistry, 20(2):129.

6. Radman, I. K., Djeri, A., Arbutina, A., Milasin, J. 2016. Microbiological Findings in Deep Caries Lesions, 63(1):7-11.

7. Agnes, A., Long, A., Best, S., Lobner, D. 2017. 'Pulp Capping Materials Alter the Toxicity and Oxidative Stress Induced by Composite Resins in Dental Pulp Culture', European Endodontic Journal, 2:1-6.

8. Mustafa, M., Saunjaya, KP., Jain, D., Sajjanshetty, S. 2012. Role of Calcium Hydroxide in Endodontics:A Review. Faculty of Dentistry Salman Bin Abdulaziz University, 1(1):66-8.

9. Jahromi, M.Z., Ranjbarian, P., Shiravi, S. 2014. 'Cytotoxicity Evaluation of Iranian Propolis and Calcium Hydroxide on Dental Pulp Fibroblasts', Journal of Dental Research, Dental Clinics, Dental Prospects, 8(3):130-3.

10.de Rezende, G. P., da Costa, L.R., Pimenta, F.C., Baroni, D.A. 2008. 'In vitro antimicrobial activity of endodontic pastes with propolis extracts and calcium hydroxide: A preliminary study', Brazilian Dental Journal, 19(4):301-5.

11.Sabir, A., Mooduto, L., Kaelan, C., Horax, S. 2016. 'Impact of the use of ethanolic extract of propolis, flavonoid and non-flavonoid propolis for direct pulp capping in collagen type i density', Brazilian Journal of Oral Sciences, 15(4):264-8.

12.Martinotti, S. and Ranzato, E. 2015. Propolis: a new frontier for wound healing?, Burns \& Trauma. Burns \& Trauma, 3(1):9.

13. Ameliana, Y. 2014. Daya antibakteri penambahan Propolis pada zinc oxide eugenol dan zinc oxide terhadap kuman campur gigi molar sulung non vital The antibacterial effect of propolis additional to zinc oxide eugenol and zinc oxide on polybacteria of necrotic primary molar , 47(4):198-201.

14. I Komang Evan W. 2009. Daya Antibakteri Ekstrak Propolis Apis Melifera spp. Terhadap Bakteri Campur Karies Dentin Profunda. Skripsi. Surabaya: Fakultas Kedokteran Gigi Universitas Airlangga.Islamie, R., Puspita, K.D. 2015. Uji Potensi Antibakteri Ekstrak Etanol Kulit Batang Alpukat Terhadap Pertumbuhan Bakteri Staphylococcus Aureus dan Pseudomonas aeruginosa. Jurnal Ilmiah Sains dan Teknologi. pp. 41-50.

15. Ozorio, J.E., Carvahlo,E.F., Oliveira, D.A., Neto, M.D., Perez, D.E. 2011. 'Standarized Propolis Extract and Calcium Hydroxide as Pulpotomy Agents in Primary Pig Teeth'. Journal of Dentistry for Children, 79(2):53-8.

16. Leo, L.M. 2017. Kombinasi Kalsium Hidroksida-Propolis Terhadap Jumlah Kolonisasi Lactobacillus acidophilus. Skripsi. Surabaya: Fakultas Kedokteran Gigi Universitas Airlangga.

17. Lucindari G.P. 2018. Daya Antibakteri Ekstrak Kulit Buah Kakao (Theobroma caco L) Terhadap Bakteri Campur Karies Dentin Profunda. Skripsi. Surabaya: Fakultas Kedokteran Gigi 
Universitas Airlangga.

18.Parolia, A., Kundabala, M., Rao, N., Acharya, S.R., Agrawal, P., Mohan, M., Thomas, M. 2010. 'A comparative histological analysis of human pulp following direct pulp capping with Propolis, mineral trioxide aggregate and Dycal', Australian Dental Journal, 55(1):59-64

19.Asmoro, FF. 2016. Perbedaan daya antibakteri kalsium hidroksida dengan dan tanpa penambahan propolis terhadap Enterococcus faecalis. Skripsi Fakultas Kedokteran Gigi Universitas Airlangga Surabaya.

20.Mori, G. G., Rodrigues, S. and Tieko, S. 2014. 'Biocompatibility of a Calcium Hydroxide-Propolis Experimental Paste in Rat Subcutaneous Tissue',25:104-8. 